\title{
A Proposal on the Decentralization of the Tasks in the Liquid Petroleum Gas Price Compensation Policy for Low-Income Households by Local Government Organizations in Thailand
}

\author{
Siwach Sripokangkul ${ }^{1}$ \\ ${ }^{1}$ Khon Kaen University, Thailand \\ Correspondence: Siwach Sripokangkul, Khon Kaen University, Thailand. E-mail: siwasri@kku.ac.th
}

Received: December 8, 2013 Accepted: March 26, 2014 Online Published: May 30, 2014

doi:10.5539/ass.v10n11p56 URL: http://dx.doi.org/10.5539/ass.v10n11p56

\begin{abstract}
Due to the retail price of Liquefied Petroleum Gas (LPG) having been raised by the Thai government by 0.50 baht per kilogram each month for 12 consecutive months from September 2013, by October 2014 the price is going to reach 24.82 baht ( 0.83 dollars) per kilogram. It affects the consumers' cost of living extensively and it has caused a massive protest. Accordingly, a price compensation policy has been employed in order to maintain the retail price of LPG for low-income citizens at 18.13 baht per kilo for 1 year. SuanDusit Rajabhat University's SuanDusit Poll was assigned to conduct a census of households', small restaurants', and food shops' LPG usage; however, there was dissatisfaction with the census result. Similarly, certain local government organizations (LGOs) in Thailand were also assigned to collect additional data to promote the policy in local areas, and to assist people to buy LPG via a mobile system. However, the LGOs have not been able to assist people effectively as required, since the process outlined above has not been operated by the LGOs from the outset. In this paper, the author argues that to assign the university to collect data was impractical; further, the failure to give the assignment to the LGOs portrays ignorance of the LGOs' responsibility in terms of local government organization and it also significantly overlooks an important principle of decentralization theory. In summary, it is suggested that for future local policies or projects, the government should decentralize those tasks to the LGOs directly since the LGOs operate for the benefit of local people; as a result, the people would have their needs met and the tasks would be run smoothly, effectively, and worthily.
\end{abstract}

Keywords: decentralization, decentralization of tasks, local government organizations in Thailand, liquefied petroleum gas price float, price compensation policy for low-income people

\section{Introduction}

Liquefied petroleum gas (LPG) is commonly used for cooking in Thailand, and therefore many small restaurants and food vendors, who are mostly poor, must use it for earning a living. With this in mind, the previous populist government did not increase the price since it would potentially affect the people in their political stronghold areas. Though the LPG market price is higher than the fixed price of 18.13 baht per kilo, the difference was subsidized by using money from Thailand's Oil Stabilization Fund (Oil Fund).

However, the Yingluck Shinawatra government has emphasized that the reasons for increasing the price are: 1) to be fair to people who pay taxes so that they do not pay an additional rate to stabilize the LPG price; 2) to help balance the Oil Fund in the last few years (from 2008-2012) because it had to provide around 4,000 million dollars to fix the LPG price And if the price were not raised, by 2015 the government would have to spend around 6,500 million dollars on balancing the LPG price; 3)to limit this particular channel of LPG usage as the household LPG price for cooking is cheap and stable compared with the industrial or transportation LPG price which has resulted in some people trying to illegally use household LPG in industrial and transportation activities; 4)to eliminate the smuggling of LPG across borders since it is only $18.13 \mathrm{baht} / \mathrm{kg}$. in Thailand, but it is $59 \mathrm{baht} / \mathrm{kg}$. in Vietnam, $49 \mathrm{baht} / \mathrm{kg}$. in Laos, $45 \mathrm{baht} / \mathrm{kg}$. in Myanmar, $34 \mathrm{baht} / \mathrm{kg}$. in Indonesia, and $20 \mathrm{baht} / \mathrm{kg}$. in Malaysia; and 5) to float the price so that it is the same as the world market price (SuanDusit Poll, 2013a; The Ministry of Energy, 2012).

The LPG price has increased, and is increasing, all over Thailand since September 1, 2013 at 0.50 baht per kilogram per month for 12 months continuously; therefore, by October 2014, the price is going to reach 24.82 
baht per kilogram and it is expected that it will reach 30.13 baht within 2015 . The government explained that adding to the LPG price at $0.50 \mathrm{baht} / \mathrm{kg}$. per month would increase the cost of food by only $0.20-0.30$ baht per item on a menu. Therefore, Mr. Yanyong Phuangrach, the Deputy Minister of Commerce, notably stated that "If any restaurants increase the food price excessively, those would be fined 140,000baht (4,600 dollars) or imprisoned for not more than 7 years or both." (Daily News, October 3, 2013).After this policy was implemented, people who were not satisfied planned to collect 50,000 signatures to petition for the removal of the Minister of Energy. Even though the protests in Thailand did not turn out as badly as those in Sudan in September 2013, complaints over the hikes in the price of LPG from low-income people and restaurants still arise. For example, Mrs. Julaporn Sasorn, a food vendor, stated that "I thought it should not have been raised, since nowadays it is hard to sell food and the cost of living is still the same. That is why people do not want to buy pricey food." Similarly, Miss Sujikarn Jambhab,a company employee, added that "Not only has the LPG price been raised but also raw food is going to be more expensive; in contrast, our salaries are still the same and therefore we are not going to survive"(AECNEWS, 2013). Raising the LPG price causes chaos among Thais as shown in Figure 1.

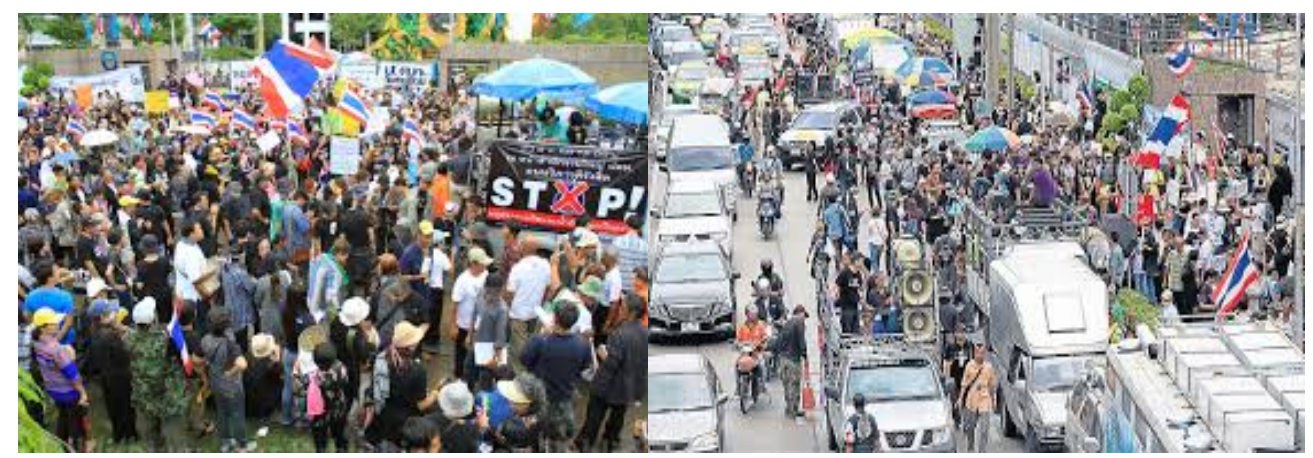

Figure 1. Supporters of the foundation for consumers and other people's networks gathered at the PTT head office on Vibhavadi-Rangsit Road to protest against the plan to float the price of cooking gas

Bangkok Post, August 23, 2013

Nevertheless, it should be noticed that in December 2012, the government had approved to the fixing of the LPG price for low-income households along the following parameters: 1) low-income households that use less than 90 units of electricity per month, which consisted of 7,430,639 households, and 2) shops less than 50 square meters in size, food vendors, and houses without electricity. Those included in the first parameter could be determined from the inspection of electricity bills, whereas for the second parameter the government hired the SuanDusit Poll to collect data throughout Thailand at a cost of 1.2 million dollars which was paid for by taking out this sum of money from the Oil Fund. (Matichon, March 16, 2013)

In the next part, the author will discuss some problems arising from when the SuanDusit Poll was assigned to collect the data. Further, the author will argue that this case is an important exemplar of the government's ignorance and distrust of the LGOs and the decentralization theory.

\section{Problems and Obstacles of SuanDusit Poll's Database}

SuanDusit Poll is one of Thailand's best-known organizations for conducting public opinion surveys and has been often been hired by both the public and private sectors to survey many issues since 1994.As it was assigned to collect the data on the shops of less than 50 square meters, food vendors, and households without electricity all over Thailand (77 provinces), it chose to hire provincial universities as subcontractors between February May 2013 to collect the data needed. This survey was not conducted as a poll but as a census; therefore, to collect the data, the universities had to survey all target groups thoroughly and collect the data in detail in order to confirm the citizens' presence at various locations by specifying GPS coordinates, inspecting the citizens' identity cards (ID), and viewing the shops' photos along with the names, food types, LPG cylinders' sizes, monthly LPG consumptions, etc. After the survey, coupons were given away to those entitled to claim the LPG at the fixed price.

Each university assigned its students to survey and fill in the data through the SuanDusit Poll website manually. As a result, many crucial problems and obstacles were found for the following reasons: 1) the time frame was in the final examination week; 2) even if it had not been in the final examination week, students could work only at theweekend; 3) some places ,especially in the case of large provinces, are in remote areas, which students could 
not reach; 4) not only are some people located in remote areas, but also in those areas people may live far from each other; 5) some students were not good at navigation; 6) most of the target groups did not bring their ID with them or forgot their ID number, resulting in loss of the chance of obtaining coupons for the LPG fixed price, unfortunately; 7) the distrust problem; the target groups distrusted the students and also were not sure if this survey would be able to help them; 8) the uncooperativeness problem; the target groups did not cooperate in providing their ID or photos as they thought that it was a scam or a tax raising exercise and some students were forced to delete photos that they had taken or to write down the names and ID as evidence, etc; 9) the recent political crises in Thailand; the target groups were afraid of being used as protesters since the students asked for their ID; 10) students could not reach some areas in southern Thailand because of the unstable and critical situations which occurred continuously; 11) the lack of advertising of the project via national and local media caused distrust among the target groups; and 12) some universities did not pay attention to their survey area.

Consequently, the census completely failed since it could not collect details of all those within the target groups who would qualify for the fixed price compensation policy despite the fact that this policy is affecting their quality of life. The expected numbers were 500,000-550,000 subjects, but the census surprisingly reported only 168,529 subjects. Many large provinces had very low numbers, for example 19,000 subjects in Bangkok, 2,000 subjects in Songkla, Chonburi, and Chantaburi, 1,500 subjects in Mahasarakham and Chiang Rai, and 1,200 subjects in Khon Kaen; this is most surprising as there are many universities and business activities in the northeast. (Matichon, March 16, 2013; SuanDusit Poll, 2013b)

Next, in July 2013, the government assigned the LGOs to collect more data from the target groups and report back to the SuanDusit Poll; moreover, the LGOs were expected to make local people understand the reasons for the LPG price rise, and assist them in registering themselves online via mobile phone in order to claim the fixed LPG price. This process was a mess because the people have to register via mobile phone to confirm their right. They must specify a shop where they usually buy LPG cylinders and every time they want to buy they have to send an SMS to report the number, size of the LPG cylinders, and from which distributer they would like to buy. The government will support LPG consumption at 18 kilograms per 3 months for those households using not more than 90 units of electricity per month and 150 kilograms per month for small restaurants and food vendors.

Arising from the situation above, some significant problems were found and analyzed as follows;-

1) To assign the SuanDusit Poll to conduct a nationwide census and work on a database was completely unsuccessful and was not worth the 1.2 million dollars budget since this organization is not good at conducting censuses; its expertise is polls and conducting a census is not the same as conducting research or polls. There is no need to do probability sampling but it is necessary to survey all target groups. Consequently, the SuanDusit Poll had to make subcontracts with local universities in order to conduct the survey which was impractical and unworthy.

2) Surprisingly, the LGOs were not assigned to work on this even though they work for local people and are located all round Thailand; there are 5,492 Sub-district Administrative Organizations, 2,081 Sub-district Municipalities, 172 Town Municipalities, 30 City Municipalities, and 2 Metropolitan Administrations (Bangkok and Pattaya).Another key point is that these LGOs could work on this case as a part-time job, which would be beneficial by offering their officers extra income. Notably, the target groups are already familiar with the LGOs, so collecting data would be easier.

3) To prevent work on the database from getting worse, the government assigned the LGOs to collect additional data and advertise the project. Because the LGOs had not been assigned to work on this at the beginning, the LGOs' officers did not know where to start, as can be seen from the policy workshop's results in August 2013 (see Figure 2). It affected the whole progress of the project; many people declined to join the project even though they would have to pay more for the LPG. Some of the Sub-district Administrative Organizations' chief executives revealed to the author that even though people were able to register again in August, they had to pay for the LPG at a higher price while they were waiting for their claims to be activated in November because the registered names had to be forwarded to the SuanDusit Poll first. Also, other executives stated that if the government had handed this project to the LGOs in the first place, such problems would never have been encountered and the project would have run more smoothly. Consequently, in October 2013, it was reported that there were only 25,000 households registered in the whole of Thailand (Energy Policy and Planning Office, 2013). 


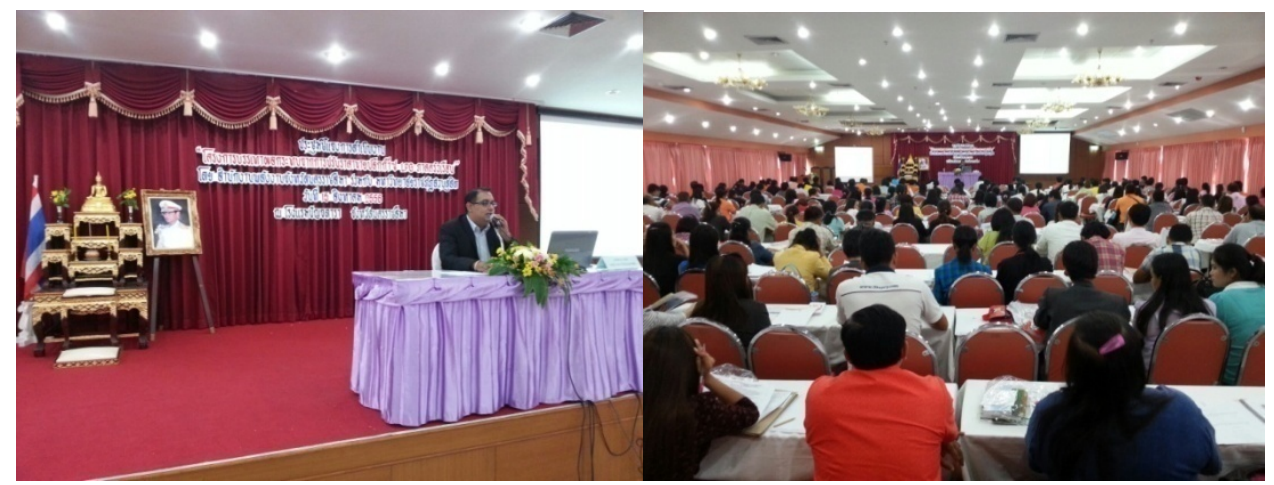

Figure 2. A workshop on the LPG price compensation policy for LGO officers in August 2013

Under those stated circumstances, the author will argue that it is a crucial exemplar of decentralization ignorance in Thailand and will state the decentralization issues in brief and then propose an effective solution.

\section{Decentralization Ignorance in Thailand}

The failure to assign the LGOs to conduct the gathering of information for the database is a crucial exemplar which could be put forward as ignoring both the LGOs' responsibilities and the concept of decentralization. Therefore, we have to understand decentralization history in Thailand and first briefly consider the structural prejudice. LGOs have been established at the levels of the Sub-district Administrative Organization, Sub-district Municipality, Town Municipality, City Municipality, Provincial Administrative Organization, and Metropolitan Administration (Bangkok and Pattaya). Decentralization had been set up by legislation in the 1991, 1997, and 2007 constitutions of The Kingdom of Thailand in order to create strong local government organizations capable of handling all local activities freely with financial independence; nevertheless, it is necessary to consider these following issues that may cause distrust or ignorance of decentralization;

1) In the Siam period, power was distributed to the provinces, but when King Rama V (1853-1910) ruled Siam, he reformed the Thai administration system in 1892 . This affected the provinces' authority immediately as they came under Bangkok's power. Strict centralization was absorbed into Thai society. The problem was that, even after the administration changed into a democracy in 1932, the centralized system still penetrated local areas which continued to rely on regional government control. For this reason, the worldview of Thai elites has not believed in decentralization and a grass-roots level administration.

2) Besides the distrust of the grass-roots level, the Thai elite's paradigm toward local people is full of problems; especially, they view local people as uneducated followers who are illogical and unprofessional. These people are not capable of self-government, so it is necessary for central government to monopolize the power to govern.

3) As the most obvious example of distrust we should consider the Determining the Decentralization Plan and Process Act of 1999.It stated that the government must manage taxes, revenues, and additional income for LGOs properly. By 2001, LGOs should be able to get $20 \%$ of their budgets from the central government income, and by 2006 LGOs should have been able to get 35\%. Sadly, 14 years have passed (2013), and the LGOs have been able to get only $27.1 \%$ which causes trouble for them; in particular, the Sub-district Administrative Organizations have not been able to help local people to improve the primary infrastructure.

4) The government's rules and regulations which emphasize 'taking control' of LGOs transform the LGOs into mock bureaucracies in local areas as they cannot perform any tasks properly even though they have been promoted by law and it seemed as if they were in an iron cage (Merton, 1957).The running of activities with local people has been taken control of by municipal and provincial clerks as central government representatives. It should be noted that those clerks who are superior to local politicians in educational background probably distrust the local politicians; they not only completely take control but also take LGOs' budgets to run projects of their own.

5) Those issues cause boredom in local people so that they do not want to participate in any political activities. Disappointingly, the elites still take the view that the locals have a very poor view of political culture and do not understand the real value of democracy. In contrast, the locals see a decentralized structure and system as trouble, so they do not want to become involved in it. This is despite the fact that, since the coup d'état in 2006, many Thai and foreign scholars have stressed that the morality and democratic understanding of Thailand's local people is higher than the middle class in Bangkok and big cities. 
The problems above arise from ignorance and distrust in decentralization; as a result, Thai people have no chance to achieve the meaningful importance of local government. For this reason, before the author proposes a way to resolve the LPG issue and help those low income citizens with the LPG crisis, the author needs to note the importance of decentralization and LGOs in order to make Thai society realize their importance.

\section{Messages for Thai Society: The Importance of Decentralization}

Decentralization has been a great development in many countries since the 1980s. Decentralization, theoretically, includes: 1) financial decentralization; LGOs are able to manage their budgets and earn their own incomes; 2) political decentralization; LGOs are able to legislate for their own local people who can elect the executives directly; and 3) administrative decentralization; LGOs have decentralized responsibility and can manage primary infrastructure issues for local people (Grindle, 2007).

As a matter of fact, administration in the modern world views LGOs as local entities which are responsible for decentralized power to local people in self-governance and participation in public service. Game and Wilson (2011) emphasized the LGOs' 6 important public services as: 1) building the community; 2) caring for the community; 3) educating the community; 4) entertaining the community; 5) protecting the community; and 6) supporting the community. Importantly, Lewis and Catron (1996) also focused on public service being public trust; it is to work sincerely and to support public interest. This trust is also related to taxes and revenues because budgets for managing public services are from people's taxes. Further, Thompson (1985) stated that besides taxes and revenue issues, to decentralize in administration is the main aspect that must be mentioned because firstly, to manage any policies could easily affect people's daily lives and secondly, because people are affected, public policies should be based on justice.

However, a problem of concern which influences decentralization of both government and administration constantly comes from distrust in human potential, resulting from excessive beliefs in rationality and professionalism. These beliefs are based on scientific values and behaviorism in the hegemonic concept which is related to social science studies during the 20th century. Schneider and Ingram (1997) claimed that scientific values and professionalism have had an influence on making policies in the U.S. and other countries. The fast progress of science and technology also has an effect on issuing objectivity policies and an expert role is expected to solve problems such as economic crisis or unemployment. For this reason, these experts have been viewed as rational groups who are concerned about maximum utility, management in handling all risks, and the creation of administrative innovations. Conversely, people participation, fairness, and democratic values have been ignored and overlooked, despite the fact that public policy should both reflect human power values and also should measure democratic values to see how it encourages or discourages people.

Some scholars have criticized the issues above; for example, Fox (2002) noted that "when we concentrate only on rationality, it generally implies the hierarchical model of command-control, top-down, industrial-rational, and instrumental rationality models." Comparably, Adams and Balfour (2004) also pointed out that the power of knowledge in technical rationality has been institutionalized and became an administrative culture as well as being a masked administrative evil.

Undoubtedly, to assign the SuanDusit Poll to work on the database could reflect trust in terms of rationality and professionalism because the government believed that the SuanDusit Poll is valid and reliable. According to Larson's definition (1977), professionalism characteristics consisted of professional association, a cognitive scientific base, institutionalized training, licensing, work autonomy, colleague control, and a code of ethics. Definitely, these characteristics also bring about structures of authority and privilege as Denhardt Denhardt (2003) noted that active citizenship may be discouraged by the professionalization of government and its increasing dependence on "experts." They also stressed that "what is most significant and most valuable about public administration is that we serve citizens to advance the common good" and "surely, what really matters is not how efficiently we have done our jobs, but how we have contributed to a better life for all."

As mentioned above, trustworthiness toward expertise organizations comes under scientific and rational-logical beliefs; the SuanDusit Poll is a crucial exemplar of this idea. Imaginatively, if we could have gone back and reversed the decision and allowed the LGOs to conduct the census, what would the result of the LPG price compensation policy have been?

\section{A Proposal on Decentralization of the Task in the LPG Price Compensation Policy for Low-Income Households by Local Government Organizations in Thailand}

"Responsibility may well be the most important word in all the vocabulary of administration, public and private" (Mosher, 1968). 
Taking into account all of the above, the 2 target groups of the LPG price compensation policy were: 1)7,430,639 households who do not use more than 90 units of electricity per month, and 2) the estimated 500, 000-550,000 people included in those who occupy shops of not more than 50 square meters, food vendors, and houses which have no electricity but for which the SuanDusit Poll reported only 168,529 subjects.

So we should be more concerned with the LPG raising price as having a widespread effect and that the government should review the policy again since the target population is low income citizens. Therefore these people play an important role in the policy effectiveness as to whether or not it is going to attain its goals (Schneider and Ingram,1997).Though designing any policy should be focused on public involvement, the government assigned a centralized organization to conduct the census, not a decentralized organization like the LGOs, viewing it as being more important and having more expertise than the LGOs. This myth has been viewed as a social construction and it comes from some elites who distrust LGOs. Thus, the myth has continuously controlled the government's beliefs and actions. This is a result of long-lasting centralization in Thailand. This myth has also been embedded in Thai society and it has been established as a firmly institutionalized truth that frames the LGOs' responsibilities on what they should do and what they should not do.

Cheema and Rondinelli (2007) stated that decentralization could help break bottlenecks in hierarchical bureaucracies and assist local officials and the private sector to cut through complex procedures and get decisions made and implemented more quickly. Similarly, a successful policy lesson is learned from Timney (1998) who studied state energy policy development in the USA; she found 3 distinct examples of citizen participation: 1) passive in Ohio; 2) hybrid in Indiana; and 3) active in Missouri. The last was quite interesting because it was comprised of the following components: 1)citizen control; 2)citizens identify parameters; 3)being proactive and open; 4)consensus decisions; 5) citizens' role is dominant; 6)citizens articulate policy; 7)agency serves as a consultant; 8)citizens own the process; 9)citizens come in at the beginning of the process; and finally, 10)government by the people not with the people and for the people. Consequently, she noted that "the administrators should not be only the experts in the policy implementation but should become facilitators and partners with citizens so that "administrators will have to overcome the tendency to opt for the controlled process merely in the name of efficiency." She also pointed out that "to change the role of administrators from experts to facilitators, we must address some fundamental questions of democracy." That means professional administrators should not have control over administrative decisions that affect millions of citizens but should use their expertise in the service of the public to enable citizens to develop their own solutions. Finally she reminded us that "most important, it is citizens who must live with the consequences of policy decisions, not administrators."

In Thai society, conducting censuses significantly needs public involvement and trust from the target groups; in this case citizens' IDs, latest restaurant photos, and GPS coordinates are required as confirmation. As LGOs are located everywhere, they can reduce any trouble in the process and handle all mentioned matters perfectly and effectively. In addition, LGOs help decrease other problems such as accessibility; the LGOs' officers are familiar with local people and the areas, so it is easier to keep in touch with the target groups. Nevertheless, while offering the price compensation policy is a great idea for assisting the people with the cost of living, the government undermined its value and also the people because it did not assign the census to the LGOs at the beginning of the process. The author will illustrate and compare the differences between the original and proposed processes as in a Figure 3 and Table 1 below. 


\section{A) Original process}

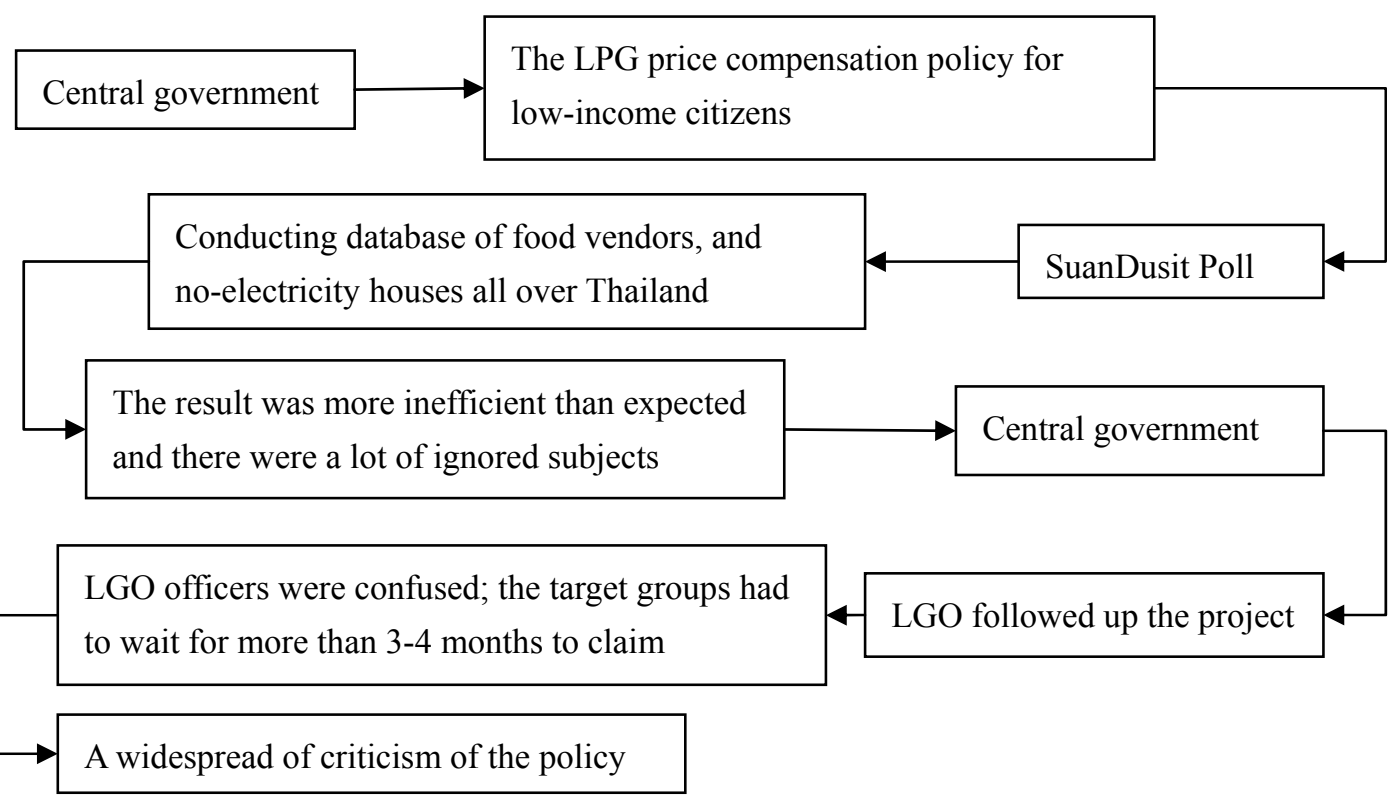

\section{B) Proposed process (if LGOs had been assigned)}

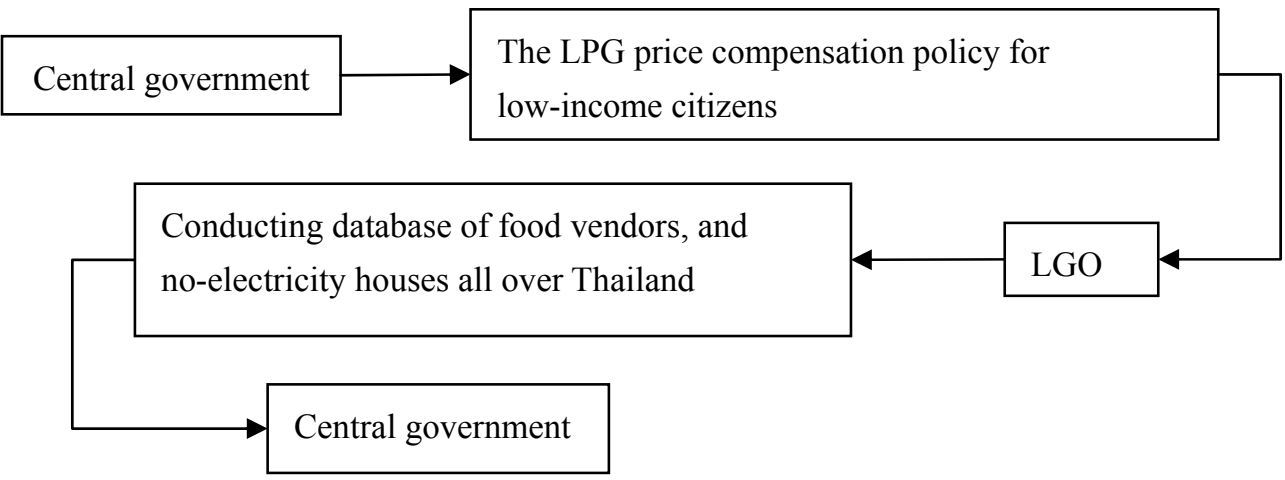

Figure 3. Maps comparing management system between the original and the proposed processes 
Table 1. Comparison of management system between the previous and the proposed processes

\begin{tabular}{|c|c|c|}
\hline Topics & SuanDusit Poll & LGO \\
\hline $\begin{array}{l}\text { 1. Database } \\
\text { management }\end{array}$ & $\begin{array}{l}\text { Strict centralization; making } \\
\text { subcontracts with local } \\
\text { universities }\end{array}$ & $\begin{array}{l}\text { Decentralization; a strong network around Thailand as } \\
\text { 5,492 Sub-district Administrative Organizations, 2,081 } \\
\text { Sub-district Municipalities, } 172 \text { Town Municipalities, } \\
\text { 30 City Municipalities, and } 2 \text { Metropolitan } \\
\text { Administrations (Bangkok and Pattaya) }\end{array}$ \\
\hline 2. Process & $\begin{array}{l}\text { Data collected by university } \\
\text { students which causes trouble and } \\
\text { emphasized only the process, not } \\
\text { the result. Because of its failure, } \\
\text { LGOs were assigned to follow up } \\
\text { the project. }\end{array}$ & $\begin{array}{l}\text { Data would be collected by LGOs' officers who are } \\
\text { familiar with locals and the areas; the officers do not } \\
\text { have to encounter problems of geography since they are } \\
\text { able to commute to the areas; also both officers and the } \\
\text { target groups know each other very well. This proposal } \\
\text { focuses on a practical working process and result; } \\
\text { importantly, LGOs are involved in this project at the } \\
\text { beginning. }\end{array}$ \\
\hline 3. Participation & $\begin{array}{l}\text { Lack of preparation of advertising } \\
\text { the policy so that local people } \\
\text { were not involved with this very } \\
\text { well. }\end{array}$ & $\begin{array}{l}\text { Locals would feel more engaged and also they could } \\
\text { measure community driven performance for } \\
\text { themselves. }\end{array}$ \\
\hline 4. Mission & $\begin{array}{l}\text { Conducting censuses as the } \\
\text { government required. }\end{array}$ & $\begin{array}{l}\text { Conducting censuses as the government required and } \\
\text { being involved with locals on the matter. Local and } \\
\text { public services become more effective. Locals could } \\
\text { gain as many benefits as possible. }\end{array}$ \\
\hline 5. Overall & $\begin{array}{l}\text { Lots of troubles which were } \\
\text { caused by claimed experts and } \\
\text { these troubles affected the target } \\
\text { group widely. }\end{array}$ & $\begin{array}{l}\text { Decentralization and task decentralization for justice, } \\
\text { equality, and lessening the difficulties of obtaining the } \\
\text { most benefits for people. }\end{array}$ \\
\hline 6. Value & $\begin{array}{l}\text { Ignoring good governance, } \\
\text { ignoring people, and not reflecting } \\
\text { the true value of democracy; it is } \\
\text { called government for the people }\end{array}$ & $\begin{array}{l}\text { Emphasizing local organization and reflecting the } \\
\text { potential value of democracy; it is called government } \\
\text { by the people }\end{array}$ \\
\hline $\begin{array}{l}\text { 7. When people } \\
\text { encounter } \\
\text { problems and } \\
\text { trouble }\end{array}$ & $\begin{array}{l}\text { People were not familiar with and } \\
\text { ignored students or the SuanDusit } \\
\text { Poll }\end{array}$ & $\begin{array}{l}\text { People are familiar with LGOs' officers in their area; } \\
\text { therefore, it is easier and more convenient. }\end{array}$ \\
\hline
\end{tabular}

As can be seen, gathering only 168,529 subjects from the entire target groups was considered as far too few. This raised anger and extensive dissatisfaction among the target groups toward the LPG price compensation policy; in fact, this policy should have been praised as it helps all low-income citizens, but it resulted in distrust and criticism.

In the author's opinion, assigning the project to the SuanDusit Poll was a wrong choice and it is suggested that letting the LGOs handle this could be an effective move and has democratic value. Therefore, in the near future, the government should decentralize local policies or projects further to LGOs directly. Besides, this would also help LGOs' officers to earn extra income and the people would have their needs met and the tasks would run smoothly, effectively, and worthily.

\section{Summary}

The LPG price compensation policy directly affects the quality of life as well as people's sense of security; regardless, the policy itself is very good for helping many poor people, but its implementation is another concern. Recently, decentralized governance and task decentralization have become acceptable among public administrations internationally, and should have a place in Thai administration as we can learn from the following summary. 
Governance is a working process and no longer related to top-down and rational-professional management. Kooiman (2003) stated that governance is the process of policy making through active and cohesive discussion among policy makers who are interconnected through a broad range of networks. Rhodes (1997) also claimed that governance means there is no one center, but multiple centers and no sovereign authority. More interestingly, we can locate the governance concept as being related to the decentralization theory. Grindle (2007) proposed that decentralization theory promises better governance and deeper democracy as public officials are held more directly accountable for their actions as citizens become more engaged in local affairs. When an LGO is related to local people, it should acquire more new responsibilities and more resources for carrying them out.When LGOs are charged with new responsibilities they are provided with new resources. Thus, LGOs can monitor both project implementation and policy implementation. Moreover, knowing what local needs are most pressing can help the disadvantaged. Similarly, Singh (2007), who studied the poor, characterized decentralized governance by effective local interaction with civil society organizations. Surely, successful decentralization allows for increased participation of the poor in community planning, project development and implementation, and problem solving. Singh concluded that successful decentralization will promote "the well-being of all people."

Most importantly, Blunt and Turner (2007) also noted that local people can access officials, and officials can be available for consultation and advice. Moreover, it is easier for locally based officials to identify local resources, both human and physical, and then mobilize them in the pursuit of locally determined developmental purposes. Besides, officials are better placed to respond rapidly to local needs as they are in the territory and aware of local conditions so that they are also well placed to make decisions and allocate resources that fit with the specific conditions prevailing in a particular territory.

Therefore, the author argues that the LPG price compensation policy to the target groups who are low- income citizens is a good intention but the process of conducting the census had a lot of problems. The author would like to suggest that, for further local policies or projects, the government should decentralize those tasks to LGOs directly, since LGOs are for local people, and should adopt the decentralized governance principles above for public administration in Thai society.

\section{References}

Adams, G. B., \& Balfour, D. L. (2004). Unmasking Administrative Evil. Armonk, New York: M.E. Sharpe.

AECNEWS. (2013). Bangkokians and LPG price problem. Retrieved October 25, 2013, from http://www.aecnews.co.th/sreport/read/602

BangkokPost. (2013, August 23). 500 rally against floating LPG price.

Blunt, P., \& Turner, M. (2007). Decentralization, Deconcentration, and Poverty Reduction in the Asia Pacific. In G. Shabbir Cheema, \& D. A. Rondinelli (Eds.), Decentralizing Governance: Emerging Concepts and Practices. Washington, D.C.: Brookings Institution Press.

Cheema, G. S., \& Rondinelli, D. A. (2007). From government decentralization to decentralized governance. In G. Shabbir Cheema, \& D. A. Rondinelli (Eds.), Decentralizing Governance: Emerging Concepts and Practices. Washington, D.C.: Brookings Institution Press.

DailyNews. (2013, October 3). D-Day floating LPG price. (In Thai).

Denhardt, J., \& Denhardt, R. (2003). The New Public Service: Serving, Not Steering. Armonk, New York: M.E. Sharpe.

Energy Policy and Planning Office. (2013). Floating LPG price again 50 satang. Retrieved October 19, 2013, from http://www.eppo.go.th/index-T.html (In Thai).

Fox, C. J. (2002). Forum:What do we mean when say rationality in public affairs? Administrative Theory and Praxis, 24(2), 347-354.

Game, C., \& Wilson, D. (2011). Local Government in the United Kingdom. London: Palgrave Macmillan.

Grindle, M. S. (2007). Going Local: Decentralization, Democratization, and the Promise of Good Governance. Princeton, N.J.: Princeton University Press.

Kooiman, J. (2003). Governing as Governance. Thousand Oaks, CA: Sage Publications.

Larson, M. S. (1977). The Rise of Professionalism. Berkeley: University of California Press.

Lewis, C. W., \& Catron, B. L. (1996). Professional Standards and Ethics. In J. L. Perry (Ed.), Handbook of Public Administration. San Francisco: Jossey-Bass. 
Matichon. (2013, March 16). Countdown to floating LPG price. (In Thai).

Merton, R. K. (1957). Bureaucratic Structure and Personality. In Social Theory and Social Structure. Glencoe, IL: Free Press.

Mosher, F. C. (1968). Democracy and the Public Service. New York: Oxford University Press.

Rhodes, R. A. W. (1997). Understanding Governance: Policy Networks, Governance, Reflexivity and Accountability. Buckingham, UK: Open University Press.

Schneider, A. L., \& Ingram, H. (1997). Policy Design for Democracy. Kansas: University Press of Kansas.

Singh, N. (2007). Decentralization and legal empowerment of the poor. In G. S. Cheema, \& D. A. Rondinelli (Eds.), Decentralizing Governance: Emerging Concepts and Practices. Washington, D.C.: Brookings Institution Press.

SuanDusit Poll. (2013a). Document for moderator training in price compensation policy for low-income households. Bangkok: SuanDusitPoll. (in Thai).

SuanDusit Poll. (2013b). Survey form of price-compensation policy for low-income people. Retrieved October 19, 2013, from http://dusitpoll.dusit.ac.th/qn/index.php. (In Thai).

The Ministry of Energy. (2012). Truth Today of LPG. Bangkok: The Ministry of Energy. (In Thai).

Thompson, D. (1985). The possibility of administrative ethics. Public Administration Review, 45(5), 555-561. http://dx.doi.org/10.2307/3109930

Timney, M. M. (1998). Overcoming Administrative Barriers to Citizen Participation Citizens as Partners, Not Adversaries. In C. S. King, \& C. Stivers (Eds.), Anti-Government Era. Thousand Oaks, CA: Sage Publications.

\section{Copyrights}

Copyright for this article is retained by the author(s), with first publication rights granted to the journal.

This is an open-access article distributed under the terms and conditions of the Creative Commons Attribution license (http://creativecommons.org/licenses/by/3.0/). 